\title{
Kurikulum dan Pendidikan Nasionalisme di Pondok Pesantren Tremas
}

\author{
Mukodi Mukodi \\ STKIP PGRI Pacitan
}

Email: mukodisumarno@gmail.com

\begin{abstract}
This research aims to describe the curriculum design in Pondok Tremas; to measure the concept of nationalism in Pondok Tremas; to describe the nationalism education design of curriculum at Pondok Tremas; and make a model for strengthening nationalism in Pondok Tremas. This research is a grounded research model developed by Noeng Muhadjir with the naturalistic paradigm of Guba and Lincoln. The research sample was taken by using purposive sampling in Pondok Tremas Pacitan. The results showed that the curriculum design at Pondok Tremas is a salafiyah style (traditional) leading to seven santri daily activities, including: religious book reading, religious practices, musabaqah, implementation of reward and punishment, discussion, khitābiyah forum, and study of bahts al-masāil. The concept of strengthening nationalism in Pondok Tremas is carried out through the study of Kitab Kuning. The design of nationalism education in Pondok Tremas curriculum uses Ralph W. Tyler's development model theory, expressed through: thought (a study of Kitab Kuning), heart (in the form of wirid and istigatsah); feel (in the implementation of students' five souls, including; simplicity, independence, brotherhood, freedom, modesty); and work (in the form of various community activities). The model of strengthening nationalism in Pondok Tremas is carried out through two domains: strengthening nationalism in the form of thought and strengthening nationalism in the form of action.
\end{abstract}

Keywords: curriculum, nationalism, radicalism, Pondok Tremas, transnational Islam

\section{Abstrak}

Tujuan penelitian ini adalah untuk mendeskripsikan sketsa kurikulum di Pondok Tremas; untuk menakar konsep nasionalisme di Pondok Tremas; untuk mendeskripsikan rancangan pendidikan nasionalisme dalam kurikulum di Pondok Tremas; dan untuk membuat model penguatan nasionalisme di Pondok Tremas. Penelitian ini merupakan model grounded research yang dikembangkan oleh Noeng Muhadjir dengan paradigma naturalistik Guba dan Lincoln. Sampel penelitian dilakukan secara purposive, yaitu Pondok Tremas Pacitan. Hasil penelitian ini menemukan sketsa kurikulum di Pondok Tremas bercorak salafiyah (tradisional) dan mengarah pada tujuh aktifitas keseharian santri, meliputi: pengajian kitab, praktik ibadah, musabaqah, pelaksanaan reward dan punishment, forum musyawarah, forum khitābiyah, dan kajian baths al-masāil. Konsep penguatan nasionalisme di Pondok Tremas dilaksanakan melalui pembelajaran kitab kuning. Rancangan pendidikan nasionalisme dalam kurikulum Pondok Tremas menggunakan teori model pengembangan Ralph W. Tyler yang diekspresikan melalui olah pikir, berupa kajian kitab kuning, olah hati, berupa wirid dan istighasah; olah rasa, berupa pelaksanaan panca jiwa santri, meliputi keserderhanaan, kemandirian, persaudaraan, kebebasan, kesahajaan; dan olah karsa, berupa beragam kegiatan kemasyarakatan. Model penguatan nasionalisme di Pondok Tremas dilakasanakan melalui dua ranah, yakni penguatan nasionalisme dalam bentuk pemikiran dan penguatan nasionalisme dalam bentuk tindakan.

Kata kunci: kurikulum, nasionalisme, radikalisme, Pondok Tremas, Islam transnasional

\section{A. Pendahuluan}

Hasil survei nasional pada 2017, Wahid Institute Yenny Wahid terkait dengan radikalisme agama di Indonesia mengalami peningkatan. Setidaknya ada sekitar 600 ribu orang atau 0,4 persen dari jumlah penduduk Indonesia telah melakukan tindakan radikal. ${ }^{1}$ Hasil survey tersebut didukung oleh Survei SMRC 2017 dan survei Alvara 2018 yang menegaskan dominannya Islam transnasional di Indonesia. Survei SMRC 2017 menyebutkan bahwa setidaknya ada 79,3 persen responden menyatakan, NKRI adalah yang terbaik di Indonesia, namun 9,2 persen responden setuju apabila NKRI diganti menjadi negara Islam (negara

${ }^{1}$ republika.co.id, Senin, 27 Maret 2017, 21:16 WIB 
khilafah). Sementara itu, survei Alvara Research Center 2018 menegaskan fenomena serupa. Survei tersebut, menemukan sebagian kalangan milenial (kelahiran akhir 1980-an dan awal 1990-an) menyepakati konsep negara Islam sebagai bentuk negara. Survei dilakukan kepada 4.200 responden, terdiri dari 2.400 peserta didik di seluruh Indonesia dan 1.800 perwakilan mahasiswa. Menurut survei Alvara mayoritas generasi milenial tetap memilih dan menghendaki NKRI sebagai bentuk negara. Namun, ada 17,8 persen peserta didik yang setuju negara Islam sebagai bentuk negara ideal. Alvara juga melakukan survei terhadap 1.200 kalangan profesional. Ironisnya, ada 15,5 persen dari kalangan tersebut menyetujui Islam sebagai ideologi negara. ${ }^{2}$ Belum lagi merebaknya klaim-klaim kebenaran atas nama Islam di perkotaan via jamaah salafi, Wahabi, dan Hizbut Tahrir Indonesia. ${ }^{3}$

Secara faktual penyebaran paham radikalisme ${ }^{4}$ dan Islam transnasional akhir-akhir ini semakin masif. Hal ini sebagai dampak pemanfaatan internet dan media sosial. Isu radikalisme dan Islam transnasional telah menjadi isu global yang juga ikut berpengaruh pada kehidupan bangsa Indonesia, utamanya umat Islam. Banyak terjadi pergeseran pemahaman sehingga beranggapan bahwa nasionalisme dan Islam merupakan dua hal yang harus dipertentangkan. Padahal, tidak demikian adanya. Pesantren sebagai salah satu lembaga pendidikan tertua di Indonesia di masa lalu telah mengajarkan bahwa nasionalisme dan Islam bukan merupakan hal yang harus dipertentangkan. Pondok pesantren di masa lalu telah membuktikan bahwa nasionalisme merupakan salah satu bagian dari Islam sehingga semangat Islam mampu mendukung tumbuh dan berkembangnya jiwa-jiwa nasionalisme. Berbekal itulah para kiai dan santri pesantren ikut berjuang merintis, membela dan mempertahankan kemerdekaan Indonesia. $^{5}$

Penyebaran paham radikalisme dan Islam transnasional sedikit banyak telah berpengaruh pada kehidupan umat Islam di Indonesia, tak terkecuali juga kehidupan di Pesantren. Kondisi ini harus segera diantisipasi terutama dalam pendidikan dan penanaman nilai-nilai di pesantren sebagai salah satu lembaga pendidikan tertua di Indonesia. Menurut Mukodi dan Afid Burhanuddin bahwa Islam, dan nasionalisme pada hakikatnya merupakan satu pertalian yang saling berkelindan. Di Indonesia, praktik keduanya, dari waktu ke waktu saling melekat satu sama lainnya. Lebih dari itu, pendidikan politik di dunia pondok pesantren menjadi salah satu tempat reproduksi calon pemimpin yang ideal di Indonesia, ${ }^{6}$ tak terkecuali memperkuat nasionalisme.

Dalam konteks itu, diperlukan adanya kurikulum dan rancangan pendidikan nasionalisme yang disemaikan di pondok-pondok pesantren di Indonesia. Argumentasinya banyak hal, di antaranya: (1) pondok pesantren adalah tempat mereproduksi calon ulama, calon ustadz/ustadzah, calon tokoh masyarakat, dan sejenisnya; (2) pondok pesantren menjadi salah satu tempat yang sangat strategis untuk mengukuhkan nilai-nilai nasionalisme; (3) pondok pesantren menjadi media yang sangat efektif untuk menumbuhkembangkan nilai-nilai toleransi dan deradikalisasi; (4) pondok pesantren menjadi arena dan habitus yang baik untuk mempraktikkan uswatun hasanah (contoh yang baik) dalam pelaksanaan nasionalisme dan deradikalisasi. Konsep dan gagasan mengenai kurikulum, nasionalisme dan deradikalisasi di

\footnotetext{
${ }^{2}$ Yaqut Cholil Qoumas, 'Menjaga Rumah Pancasila Dari Ancaman Ideologi Islam Transnasional', Tirto.Id (Jakarta, June 2019), p. 1.

${ }^{3}$ Yaqut Cholil Qoumas. Yaqut Cholil Qoumas.

${ }^{4}$ Menurut Samsul Ma'arif radikalisme dapat diklasifikasi menjadi dua, yakni radikalisme pikiran dan radikalisme tindakan. Radikalisme pikiran melahirkan fundamentalisme dan radikalisme tindakan melahirkan terorisme. Lihat, Samsul Ma'arif, 'Ideologi Pesantren Salaf: Deradikalisasi Agama Dan Budaya Damai', Ibda' Jurnal Kebudayaan Islam, Vol. 12.No. 2 (2014), 201.

${ }^{5}$ Mukodi, 'Pesantren Dan Upaya Deradikalisasi Agama', Jurnal Walisongo, 23.Issue 1 (2015).

${ }^{6}$ Mukodi, 'Pesantren Dan Pendidikan Politik Di Indonesia: Sebuah Reformulasi Kepemimpinan Islam Futuristik’, Al-Tahrir Jurnal Pemikiran Islam, 16 (2016), 462-63.
} 
pondok pesantren pada hakikatnya telah banyak mendapatkan respon dari para peneliti sebelumnya. Hal ini dapat dicermati dari beberapa hasil riset para peneliti terdahulu, diantaranya dilakukan oleh Mukodi $^{7,8}$ dan Afid Burhanuddin, ${ }^{9}$ Nasihun Amin, ${ }^{10}$ Sutarjo Adisusilo, ${ }^{11}$ Nurrohman, ${ }^{12}$ Abdul Rasyid Saliman dan Rio Armanda Agustian. ${ }^{13}$

Riset-riset terdahulu tersebut di atas, secara eksplisit menegaskan bahwa pentingnya nasionalisme disemaikan dan ditumbuhkembangkan di pelbagai pondok pesantren di Indonesia. Hanya saja belum dijelaskan model dan bentuk penguatan kurikulum secara detail. Di area inilah riset ini akan difokuskan dan akan membahas kekurangan dari riset-riset terdahulu tersebut. Penelitian ini merupakan model grounded research yang dikembangkan oleh Noeng Muhadjir dengan paradigma naturalistik Guba dan Lincoln. ${ }^{14}$ Sampel penelitian dilakukan secara purpossive, yaitu Pondok Tremas Pacitan. Tujuan penelitian ini adalah untuk: (1) mendeskripsikan sketsa kurikulum di Pondok Tremas; (2) menakar konsep nasionalisme di Pondok Tremas; (3) mendeskripsikan rancangan pendidikan nasionalisme dalam kurikulum di Pondok Tremas; (4) membuat model penguatan nasionalisme di Pondok Tremas. Sumber data primernya berupa kurikulum dan pendidikan nasionalisme Pondok Pesantren Tremas. Data sekundernya adalah beragam artikel tentang kurikulum dan pendidikan nasionalisme di pondok pesantren. Datanya kemudian diolah secara induktif-naturalistik-interpretif.

\section{B. Sketsa Kurikulum Di Pondok Pesantren Tremas}

Pada umumnya, kurikulum di pondok pesantren selalu dikesampingkan sejak pra kemerdekaan hingga masa sekarang. Bahkan, dipandang sebelah mata, walau pun sebenarnya beragam materi ajar pendidikan yang mengarah pada satu kerangka dasar kurikulum sudah ada di dalam pesantren. Padahal, keberadaan kurikulum itu sendiri hakikatnya merupakan sebuah media untuk mewujudkan tujuan dari proses pendidikan itu sendiri. Kurikulum sesungguhnya merupakan kumpulan mata ajar yang diajarkan secara sistematis dan dievaluasi secara proporsional untuk mewujudkan cita-cita ideal. ${ }^{15}$ Sementara itu, dalam bahasa Arab kurikulum sering disebut "manhaj", artinya jalan terang dan dilalui manusia. ${ }^{16}$

Kurikulum adalah salah satu komponen terpenting lembaga pendidikan formal yang digunakan sebagai acuan untuk menentukan isi pengajaran, mengarahkan proses pendidikan, landasan keberhasilan dan kualitas hasil pendidikan. ${ }^{17}$ Demikian pula bagi pondok pesantren, kurikulum menjadi instrumen yang penting, walau tidak menjadi satu-satunya instrumen

\footnotetext{
${ }^{7}$ Mukodi, 'Pesantren Dan Upaya Deradikalisasi Agama'.

${ }^{8}$ Mukodi, 'Pesantren Dan Pendidikan Politik Di Indonesia: Sebuah Reformulasi Kepemimpinan Islam Futuristik'.

${ }^{9}$ Mukodi dan Afid Burhanuddin, 'Dialektika Keilmuan Pondok Pesantren Tremas Dalam Perspektif Gender', Jurnal Penelitian Pendidikan, 7. Issue 1 (2015).

${ }^{10}$ Nasihun Amin, 'Menyemai Nasionalisme Dari Spirit Agama: Upaya Meredam Radikalisme Beragama', Jurnal Teologia, 23.Issue 1 (2012).

${ }^{11}$ Sutarjo Adisusilo, 'Nasionalisme-Demokrasi-Civil Society’ (Jakarta: www.google, diakses 28/06/2019, pukul 16.03., 2019).

${ }^{12}$ Nurrohman, Pesantren Sebagai Penangkal Radikalisme Dan Terorisme: Studi Terhadap Pandangan Pimpinan Pesantren Di Bandung Tentang Jihad, Kekerasan dan Kekuasaan, Serta Cara Menangkal Munculnya Radikalisme dan Terorisme (Jakarta, 2010).

${ }^{13}$ Abdul Rasyid Saliman dan Rio Armanda Agustian, 'Menguatkan Nasionalisme Baru Generasi Muda Yang Berkarakter (Dalam Upaya Mengembangkan Model Pencegahan Radikalisme dan Terorisme Di Kampus)', in Seminar Nasional Hukum Universitas Negeri Semarang (Semarang: Universitas Negeri Semarang, 2017), pp. 129-34.

${ }^{14}$ Noeng Muhadjir, Metodologi Penelitian Paradigma Positivisme Objektif Phenomenologi Interpretif Logika Bahasa Platonis, Chomskyist, Hegelian \& Hermeneutik Paradigma Studi Islam Matematik Recursion, SeftTheory \& Stuructural Equation Modeling Dan Mixed, Edisi VI P (Yogyakarta: Rake Sarasin, 2011).

${ }^{15} \mathrm{Tn}$, 'Kamus Besar Bahasa Indonesia (KBBI) Online' (https://kbbi.web.id/).

${ }^{16}$ H. Langgulung, Manusia Dan Pendidikan: Suatu Analisa Psikologi Pendidikan (Jakarta: Bumi Aksara, 1986).

${ }^{17}$ Harun Nasution, Kurikulum Dan Pengajaran (Jakarta: Bumi Aksara, 1995).
} 
terpenting dan mengantarkan kesuksesan bagi para santri. Namun praktiknya, kurikulum sering kali tidak mampu adaptif dengan kecepatan perubahan yang ada. Oleh karena itu, pengembangan dan pembenahan kurikulum harus senantiasa dilakukan secara berkesinambungan. ${ }^{18}$

Bahkan, menurut al-Syaibani kurikulum didefinisikan sebagai jalan terang, atau jalan terang yang dilalui oleh manusia pada berbagai bidang kehidupannya. Tujuannya adalah untuk mengembangkan pengetahuan, keterampilan, dan sikap manusia. Lebih dari itu, ia pun menjelaskan bahwa kurikulum juga dapat diartikan sebagai:

“...sejumlah kekuatan, faktor-faktor pada alam sekitar pengajaran dan pendidikan yang disediakan oleh sekolah bagi murid-muridnya di dalam dan di luarnya, dan sejumlah pengalaman-pengalaman yang lahir daripada interaksi dengan kekuatan-kekuatan dan faktor-faktor ini". ${ }^{19}$

Selaras dengan pendapat al-Syaibani, Abdul Mujib pun mengatakan bahwa kurikulum pada prinsipnya merupakan seperangkat perencanaan dan media untuk mengantar lembaga pendidikan dalam mewujudkan tujuan pendidikan yang diimpikan. Ia menjelaskan bahwa sesungguhnya konsep dasar kurikulum sebenarnya tidak sesederhana itu, karena kurikulum dapat didefinisikan menurut fungsinya, yakni: a) Kurikulum sebagai program studi. Diartikan sebagai seperangkat mata pelajaran yang mampu dipelajari oleh peserta didik di sekolah atau institusi pendidikan lainnya; b) Kurikulum sebagai konten. Diartikan sebagai informasi atau data yang tercantum dalam beragam buku kelas; c) Kurikulum sebagai kegiatan terencana. Diartikan sebagai kegiatan yang direncanakan tentang kompetensi-kompetensi yang akan diajarkan dengan cara, dan metode pencapaiannya; d) Kurikulum sebagai hasil belajar. Diartikan sebagai seperangkat tujuan holistik (utuh) untuk mendapatkan suatu hasil tertentu tanpa melakukan spesifikasi cara-cara yang dituju dalam pencapaiannya; e) Kurikulum sebagai reproduksi kultural. Diartikan sebagai transfer of knowledge dan refleksi butir-butir kebudayaan masyarakat, agar dimiliki dan dipahami oleh peserta didik; f) Kurikulum sebagai pengalaman belajar. Diartikan sebagai keseluruhan pengalaman belajar yang direncanakan di bawah koordinasi seorang pimpinan; g) Kurikulum sebagai produksi. Diartikan sebagai seperangkat tugas yang harus dilakukan untuk mencapai hasil yang telah ditetapkan. ${ }^{20}$

Dalam perspektif pendidikan Islam, tak terkecuali pendidikan pesantren, kurikulum sesungguhnya memiliki lima ciri khas utama, yaitu: a) lebih memprioritaskan tujuan agama dan akhlak pada berbagai tujuan, serta berbagai kandungan, metode, teknik dan alat yang bercorak keislaman; b) berorientasi pada pengembangan dan bimbingan terhadap segala aspek pribadi santri mulai dari aspek pengetahuan (intelektual), spiritual, psikologis, dan sosial; c) menitikberatkan pada perhatian pendidikan seni, pelbagai pengalaman, dan kegiatan pengajaran yang beragam; d) menekankan pada aktivitas pendidikan jasmani, latihan fisik, pengetahuan teknik, latihan kejuruan, dan bahasa-bahasa asing; dan e) menekankan pada kebebasan keragaman berpikir dan akomodatif terhadap bakat, serta potensi yang dimiliki santri. ${ }^{21}$

Kurikulum di suatu pesantren pun dapat dijadikan salah satu dasar untuk mengidentifikasi apakah suatu pesantren termasuk dikategorikan sebagai pesantren salafiyah, khalafiyah, atau perpaduan keduanya. Umumnya, jika muatan materi di suatu pesantren menitikberatkan pada teks-teks klasik (kitab kuning) dan metodologi pengajarannya dilaksanakan secara tradisional, ia termasuk dikategorikan sebagai pondok pesantren salafiyah, sedangkan jika suatu pesantren lebih menekankan pada muatan umum, dan metodologinya

\footnotetext{
${ }^{18}$ Nurcholis Madjid, Bilik-Bilik Pesantren Sebuah Potret Perjalanan (Jakarta: Paramadina, 2010).

${ }^{19}$ O.M.A. Al-Syaibany, Falsafah Pendidikan Islam (Jakarta: Bulan Bintang, 1979).

${ }^{20}$ J. Mujib, A. \& Mudzakkir, Ilmu Pendidikan Islam (Jakarta: Kencana Prenada Media Group, 2008).

${ }^{21}$ Oemar Muhammad Al-Toumy Al-Syaibani, Filsafat Pendidikan Islam, Hasan Lang (Jakarta: Bulan Bintang, 1979).
} 
kontekstual, ia termasuk dikategorikan sebagai pondok khalafiyah. Perpaduan keduanya (salafiyah-khalafiyah) secara otomatis, ia dikategorikan sebagai pondok pesantren terpadu. ${ }^{22}$ Harus diakui, muatan mata pelajaran yang menitikberatkan pembahasan tentang nasionalisme, cinta tanah air, bela negara dan patriotisme dalam bentuk mata ajar masih kurang dominan diajarkan di pesantren. ${ }^{23}$

Berikut ini akan disajikan sketsa kurikulum Pondok Tremas sebagai sampel pondok salafiyah tua di Indonesia. Pondok Pesantren Tremas merupakan salah satu pondok tua yang ada di Indonesia. Secara geografis, pondok ini berada di Desa Tremas, Kecamatan Arjosari Kab. Pacitan, Jawa Timur. Pondok ini didirikan oleh KH. Abdul Manan pada tahun (18301862). Saat ini Pondok Tremas di bawah kepemimpinan KH. Fuad Habib Dimyathi, dan KH. Luqman Harist Dimyathi (1998-sekarang) setelah wafatnya KH. Haris Dimyathi, KH. Habib Dimyathi dan KH. Hasyim Ihsan. Adapun kurikulum Pondok Tremas dalam kajian kitab kuning adalah sebagai berikut:

Tabel 1: Kurikulum Kajian Kitab Kuning Pondok Tremas

\begin{tabular}{|c|c|c|c|}
\hline No & Kitab & No & Kitab \\
\hline 1. & صحيح البخاري & 16. & ســــلم التوفـــيق \\
\hline 2. & الإقتاع & 17. & طــب النــــــبوى \\
\hline 3. & أذَكــــار النووي & 18. & كاثفة الســـــا \\
\hline 4. & 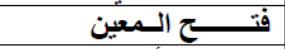 & 19. & 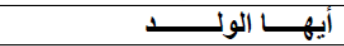 \\
\hline 5. & تفــسير الأحــــام & 20. & ذرة الناصحــــــين \\
\hline 6. & فتـــــــــ الجــــواد & 21. & موعظة المؤمنين \\
\hline 7. & تفســــــير يس & 22. & ريـــاض الصالحين \\
\hline 8. & الاثــــــباه والــــــــــائر & 23. & إرشـــــــاد العــــباد \\
\hline 9. & فتــــــ التوهاب & 24. & نصائح العـــباد \\
\hline 10. & كــفاية الاخــيار & 25. & 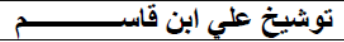 \\
\hline 11. & 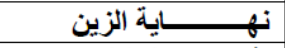 & 26. & بــــــوغ الـــــمرام \\
\hline 12. & تفـــسير الجلالين & 27. & نصائح العـــباد \\
\hline 13. & ســــــــلـم المناجة & 28. & الــــبرزنـــــــــ \\
\hline 14. & إبـــن عـــــليل & 29. & نور الظـــــــلام \\
\hline 15. & إحيأ علوم الدين & 30. & خــــلعة الفــكرية \\
\hline
\end{tabular}

Selain itu, setidaknya ada tujuh aktivitas keseharian para santri yang mengarah pada tercapainya kurikulum di Pondok Tremas, yakni: 1) pengajian kitab; 2) praktik ibadah; 3) musabaqah; 4) pelaksanaan reward dan punishment; 5) forum diskusi (musyawarah) kitab; 6) forum khițābiyah; 7) kajian bahts al-masāil. Lebih jelasnya dapat disajikan pada gambar 1 berikut ini:

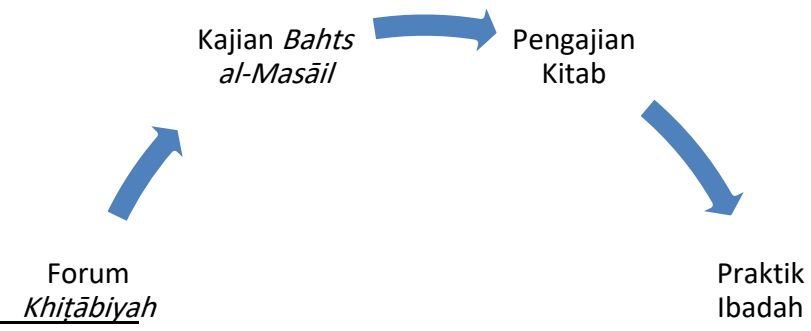

\footnotetext{
${ }^{22}$ Mukodi, Menjaga Umat: Pilar-Pilar Budaya Pondok Tremas Pacitan di Era Global, 1st edn (Yogyakarta: Lentera Kresindo, 2015).

${ }^{23}$ Hasil observasi dan wawancara dengan para santri dan ustadz/ustadzah senior pada medio bulan MaretApril 2020.

${ }^{24}$ Mukodi, Menjaga Umat Pilar-Pilar Budaya Pondok Tremas di Era Global, 1st edn (Yogyakarta: Lentera Kresindo Yogyakarta, 2015). 


\section{Gambar 1; Aktivitas Keseharian Santri Pondok ${ }^{25}$} berikut:

Adapun penjelasan dari gambar 1 tersebut di atas, secara detail akan dijelaskan sebagai

1. Pengajian Kitab (Sekolah Diniyah)

Pengajian kitab kuning di pondok pesantren disebut oleh Bruinessen sebagai salah satu tradisi agung (great tradition) di Indonesia. ${ }^{26}$ Bahkan, menurut Dhofier pada masa lalu pengajaran kitab-kitab klasik, terutama karangan ulama paham Syafi'i, adalah satu-satunya pengajaran yang diberikan dalam lingkungan pesantren. ${ }^{27}$

Pengajaran kitab kuning diajarkan secara lisan oleh para kiai atau asātid. Kitab dibacakan keras-keras oleh sang kiai di depan sekelompok santri, sementara para santri yang memegang kitabnya memberikan harakat sebagaimana bacaan sang kiai dan mencatat penjelasannya, baik dari segi lugawi (bahasa), maupun ma'nawi (makna). Ada pula santri yang mengajukan pertanyaan, tetapi biasanya terbatas pada konteks sempit isi kitab itu. Pola pengajaran kitab kuning ini dilaksanakan melalui dua cara, yakni bandongan atau wetonan ${ }^{28}$ dan sorogan. ${ }^{29}$

\section{Praktik Ibadah}

Praktik ibadah sesungguhnya merupakan intisari dari pemahaman atas teks keilmuan yang diajarkan oleh sang kiai kepada para santri di pondok pesantren. Umumnya, praktik ibadah para santri dilaksanakan secara teratur dan terjadwal. Bahkan, sudah menjadi hal yang biasa, jika sebagian besar para kiai atau pengurus pesantren menyambangi para santri di asramaasrama mereka guna memberi aba-aba atau mengajak shalat berjamaah atau shalat tahajud. ${ }^{30}$

3. Musabaqah

Aneka ragam ajang perlombaan (musabaqah) merupakan bagian daripada pendidikan dan pengajaran yang dilakukan di pondok pesantren. Tujuannya, untuk meningkatkan kualitas -praktik keilmuan atau pengamalan ibadah santri atas teks-teks keilmuan yang telah dikuasai. Ajang musabaqah ini biasanya dihelat oleh pengurus pondok pesantren atau organisasi intra

\footnotetext{
${ }^{25}$ Mukodi, Menjaga Umat: Pilar-Pilar Budaya Pondok Tremas Pacitan di Era Global.

${ }^{26}$ M.V. Bruinessen, Kitab Kuning Pesantren Dan Tarekat (Jakarta: Mizan, 1995).

${ }^{27}$ Z. Dhofier, Tradisi Pesantren Studi Pandangan Hidup Kyai Dan Visinya Mengenai Masa Depan Indonesia (Jakarta: LP3ES, 2011).

${ }^{28}$ Sistem wetonan adalah metode pengajaran di mana santri mengikuti pelajaran dengan duduk didekat sang kiai yang membacakan kitab tertentu, sementara santri menyimak kitab masing-masing dan memberikan makna kitabnya. Baca, Mukodi, Menjaga Umat: Pilar-Pilar Budaya Pondok Tremas Pacitan Di Era Global.

${ }^{29}$ Secara istilah, sorogan berasal dari kata sorog (Jawa) yang berarti menyodorkan, maksudnya santri menyodorkan kitabnya di hadapan kiai, sehingga terkadang santri itu sendiri yang membaca kitabnya di hadapan kiai, sedangkan kiai hanya menyimak dan memberikan koreksi bila ada kesalahan dari bacaan santri tersebut. Baca, D Lombard, Nusa Jawa: Silang Budaya (Jakarta: Gremedia Pustaka Utama, 2008).

${ }^{30}$ Mukodi, Menjaga Umat: Pilar-Pilar Budaya Pondok Tremas Pacitan di Era Global.
} 
pesantren di bulan-bulan tertentu seperti peringatan hari besar Islam, misalnya peringatan Isra' Mi'raj, Maulid Nabi Muhammad saw., tahun baru Hijriyah, lomba di akhirussanah (akhir tahun ajaran) di bulan Sya'ban, dan lain sebagainya. ${ }^{31}$ Perlombaannya pun beragam tergantung panitia atau pengurus pondok pesantren, misalnya lomba kebersihan kamar (gotaan) di masingmasing asrama santri, lomba membaca kitab kuning, lomba pidato, lomba bahts al-masail, bacaan tahlil, lomba hafalan nadham Kitab Alfiyah, nadham Kitab Imriti, nadham Kitab Jurumiyah, dan lain sebagainya. ${ }^{32}$

\section{Pemberian reward dan punishment}

Reward dan punishment merupakan bagian daripada mekanisme teori belajar behavioristik. ${ }^{33}$ Teori ini menganjurkan pemberian stimulus respon, berupa reward (penghargaan) dan punishment (hukuman). Dalam praktik kesehariannya, reward acapkali diberikan kepada santri yang berprestasi secara akademik, maupun pengamalan amaliyah teksteks keagamaan. Penghargaan tersebut biasanya berupa pujian secara lisan, atau berupa pemberian hadiah, sebut saja hadiah kitab atau benda-benda kebutuhan keseharian santri; sabun cuci, handuk, sarung, dan lain semacamnya ala pondok pesantren. punishment diberikan kepada para santri yang melanggar aturan, semisal tidak menyetorkan hafalan, tidak melaksanakan jamaah shalat maktubah. ${ }^{34}$

\section{Forum Diskusi (Musyawarah) Kitab}

Diskusi (musyawarah) atau dikenal dengan nama syawir merupakan salah satu penanda dari kebudayaan yang lekat dengan kehidupan pondok pesantren. Para santri dibimbing oleh para ustadz atau santri senior melaksanakan syawir sesuai dengan tingkatan. Umumnya, musyawarah dilaksanakan sehabis shalat Magrib atau shalat Isya. Durasi waktu antara satu jam hingga dua jam. Dipimpin oleh salah satu santri senior, atau bergantian sesuai dengan jadwal. ${ }^{35}$

Musyawarah dihelat dengan santai dan khidmat. Para santri duduk melingkar sembari bersila atau menjulurkan kakinya di bawah meja. Silang pendapat senantiasa mengemuka karena masing-masing santri mengemukakan argumen sesuai dengan kapasitasnya. Dinamika diskusi sangat kental dengan perdebatan yang tidak jarang disertai dengan saling ejek dan menertawai namun berlangsung tanpa perkelahian. Kajian kitab yang di musyawarahkan sesuai dengan kesepakatan, misalnya kitab fiqih, nahwu, sharaf, dan semacamnya. ${ }^{36}$

\section{Forum Khițābah}

Salah satu pendidikan berbicara di depan umum (public speaking) diberikan di pondok pesantren. Wadah yang dijadikan untuk mengasah keterampilan santri dalam menyampaikan pendapat dan gagasan di tempat umum lazimnya disebut khițābah. Tentunya, masing-masing pondok pesantren mempunyai sistem dan mekanisme yang berbeda-beda dalam melaksanakan praktik khițābah-nya. Ada yang pelaksanaannya satu atau dua minggu sekali. Ada pula yang dihelat sebulan sekali. Levelnya pun, berbeda-beda. Ada yang dilaksanakan di tingkat asrama, kamar, atau tingkat sekolah. Ada pula khițābah yang diselenggarakan sebagai ajang perlombaan (musabaqah) atau semacamnya, dengan pendengar (mustami'in) yang beragam. ${ }^{37}$

7. Kajian Bahts al-Masāil

\footnotetext{
${ }^{31}$ Mukodi, Menjaga Umat: Pilar-Pilar Budaya Pondok Tremas Pacitan di Era Global.

${ }^{32}$ Hasil observasi penulis pada medio Maret-April 2020 di Pondok Tremas Pacitan

${ }^{33}$ Novi IrwanNahar, 'Penerapan Teori Belajarbehavioristik Dalam Prosespembelajaran', Nusantara (Jurnal Ilmu Pengetahuan Sosial), 1 (2016), 65-66.

${ }^{34}$ Shalat yang diwajibkan, atau shalat lima waktu.

${ }^{35}$ Mukodi, Menjaga Umat: Pilar-Pilar Budaya Pondok Tremas Pacitan Di Era Global.

${ }^{36}$ Wawancara mendalam peneliti dengan salah satu santri senior (H.K) dan pengamatan mendalam bulan Februari-Maret 2020.

${ }^{37}$ Hasil observasi pada medio Februari-Maret di Pondok Tremas Pacitan.
} 
Bahts al-masāil terdiri dua suku kata, bahts bermakna pembahasan dan masail berarti pelbagai persoalan. Bahs al-masāil pada prinsipnya merupakan pemecahan atau pembahasan atas pelbagai persoalan, baik persoalan ubudiyah, amaliyah, maupun muamalah dengan menggunakan sumber kitab-kitab rujukan fiqih mu'tabarah untuk mencari solusi. ${ }^{38}$ Tujuan kajian bahts al-masāil adalah untuk melatih kemampuan para santri agar dapat memecahkan persoalan secara ilmiah berdasarkan kitab-kitab mu'tabarah. Selain itu, bertujuan untuk melatih kesigapan para santri dalam ikut serta memberikan solusi keagamaan di masyarakat sekitar. ${ }^{39}$

Dengan demikian, poin terpenting yang harus dipahami bahwa kurikulum Pondok Tremas sampai hari ini masih mempertahankan ciri khas kurikulum salafiah. Cirinya, menggunakan al-kutub al-mu'tabarah ${ }^{40}$ dalam praktik pengajaran kitab kuning di lingkungan pondok. Beragam aktivitas lainnya, pada hakikatnya sebagai suplemen yang bersifat komplementer pendukung dalam pembelajaran didalamnya.

\section{Menakar Nasionalisme di Pondok Pesantren Tremas}

Secara etimologis, nasionalisme pada hakikatnya diambil dari kata nation yang bermakna bangsa. Bangsa adalah sekumpulan masyarakat yang berada dalam suatu daerah dan tunduk kepada kedaulatan negaranya sebagai kekuasaan tertinggi, baik ke luar, maupun ke dalam. ${ }^{41}$ Secara terminologi, nasionalisme mempunyai banyak perspektif, tergantung siapa, kapan, dan latar belakang sosial historis seseorang yang berbicara. Hanya saja, pada umumnya para ahli memiliki kesamaan substansi dan esensi pemaknaan nasionalisme. Nasionalisme dapat diartikan: a) sebagai suatu keinginan akan kemerdekaan politik, keselamatan dan prestise bangsa; b) sebagai rasa cinta pada tanah air, bahasa atau budaya, ras yang sama (patriotisme); c) sebagai dogma yang mengajarkan bahwa individu hanya hidup untuk bangsa dan bangsanya; d) sebagai suatu kebaktian suci, yang bersifat mistis terhadap organisme sosial; e) sebagai doktrin bahwa bangsanya sendiri harus dominan dibanding bangsa lain dan harus bertindak agresif. $^{42}$

Lebih dari itu, nasionalisme memiliki kerangka ideologis, yakni aspek cognitive, goal atau value orientation, strategic, dan affective. Nasionalisme sebagai ideologi dapat memerankan tiga fungsi, yaitu: menyatukan mentalitas warga bangsa, mengikat semua kelas warga bangsa, dan membangun atau memperkokoh pengaruh warga bangsa terhadap kebijakan yang diambil oleh negara. Di samping itu, nasionalisme menjadi alat perekat kohesi sosial untuk mempertahankan eksistensi negara dan bangsa. Semua negara dan bangsa membutuhkan nasionalisme sebagai faktor integratif. Artinya, perwujudan dan tujuan nasionalisme senantiasa relevan dengan tuntutan anak jamannya, Sartono Kartodirdjo berpendapat bahwa nasionalisme masih relevan, jika disertai dengan prinsip utamanya, yaitu: a) adanya jaminan kesatuan (unity) dan persatuan bangsa; b) jaminan kesamaan (equality) bagi setiap individu; c) jaminan kebebasan (liberty) individu ataupun kelompok; d) jaminan terwujudnya kepribadian (personality); e) dan prestasi (performance). Selama kelima pilar nasionalisme tersebut masih berakar kuat di suatu negara, maka nasionalisme akan tetap relevan dan terus dibutuhkan oleh setiap bangsa. ${ }^{43}$

Sementara itu, nasionalisme dalam bilik-bilik kepesantrenan di Indonesia tidak diragukan lagi. Dalam sejarah, kalangan pesantren adalah salah satu penyokong utama

\footnotetext{
${ }^{38}$ Mukodi, Menjaga Umat: Pilar-Pilar Budaya Pondok Tremas Pacitan di Era Global.

${ }^{39}$ Mukodi, Menjaga Umat: Pilar-Pilar Budaya Pondok Tremas Pacitan di Era Global.

${ }^{40} \mathrm{Al}$-kutub al-mu'tabarah adalah kitab-kitab standar yang layak dijadikan rujukan atau bahan pertimbangan dalam memutuskan sesuatu. Lihat, Shofiyullah Mz., 'Al-Kutub Al-Mu'tabarah: Kajian Atas Sumber Rujukan dalam Beristinbat Menurut NU, Muhammadiyah, dan Persis', Jurnal Asy-Syir'ah, 42.Issue 1 (2008), 38-54.

${ }^{41}$ Nasihun Amin.

${ }^{42}$ Sutarjo Adisusilo.

${ }^{43}$ Sutarjo Adisusilo.
} 
eksistensi Negara Kesatuan Republik Indonesia (NKRI). Dunia pesantren tentunya sangat identik dan lekat sekali dengan Nahdlatul Ulama (NU), dimana Resolusi Jihad adalah bukti historisnya. Kondisi kebangsaan yang sangat genting pada waktu itu, NU di bawah kepemimpinan KH. Hasyim Asy'ari mengeluarkan fatwa "Resolusi Jihad" pada tanggal 22 Oktober 1945. Isinya mewajibkan kepada seluruh umat Islam, baik pria maupun wanita mengangkat senjata melawan kolonialisme dan imperialisme yang mengancam keselamatan Negara Kesatuan Republik Indonesia. ${ }^{44}$ Dengan demikian, dunia pesantren dan nasionalisme laiknya dua sisi mata uang.

Dalam konteks kekinian, praktik nasionalisme di pondok pesantren senantiasa digelorakan dengan cara, teknik dan konsep sang kiai masing-masing. Tentunya sesuai dengan kapasitas dan pengalaman mereka, sehingga di setiap pesantren penguatan nasionalisme berbeda-beda. Hanya saja, lazimnya praktiknya tampak melalui beragam pengajaran kitab kuning (sorogan, bandongan, tahasus), ceramah keagamaan (kiai dan ustadz/ustadzah), aneka perlombaan dan praktik keseharian santri yang diajarkan melalui uswatun hasanah. Praktikpraktik tersebut, muaranya pada penguatan nasionalisme dalam jiwa para santri. ${ }^{45}$ Sekadar contoh, kajian kitab kuning yang mengajarkan nilai-nilai nasionalisme di Pondok Tremas berupa pelajaran Qira'ah yang mengkaji kitab 'Idhatun Nashi'in pada bab لوطنية'. Selain itu, biasanya para ustadz/ustadzah/para masyayikh memberikan pemahaman tentang kecintaan tanah air pada peringatan" hari nasional seperti pada saat HUT RI dan pada peringatan hari santri. Juga pada saat acara muhadharah atau acara dzibaiyyah wal khitabiyah. ${ }^{46}$

\section{Rancangan Pendidikan Nasionalisme dalam Kurikulum di Pondok Pesantren Tremas}

Pendidikan nasionalisme dalam kurikulum pondok pesantren di Indonesia menjadi keniscayaan saat ini. Beragam aksi radikalisme yang terjadi di tanah air belakangan ini merupakan pantulan dari blue print pendidikan di Indonesia. Padahal radikalisme merupakan embrio lahirnya terorisme. ${ }^{47}$ Radikalisme adalah sikap yang memimpikan perubahan secara total dan bersifat revolusioner dengan mengabaikan nilai-nilai yang ada melalui kekerasan (violence) dan aksi-aksi yang ekstrem. Ada beberapa penanda yang dapat dikenali darinya, yakni intoleran, fanatik, eksklusif dan revolusioner. Sayangnya, simpul-simpul bangunan nasionalisme kian hari kian melemah, tak terkecuali di pondok pesantren. Kajian kitab-kitab klasik yang bermuatan nasionalisme tidak lagi menjadi pilihan wajib pembelajaran di pondok pesantren.

Harus dicatat bahwa hingga kini memang masih ada beberapa kitab-kitab rujukan yang mengajarkan semangat nasionalisme, sebut saja kitab Idhatun Nasi'in karya Mustofa alGhalayain, tetapi pembelajaran kitab tersebut tidak terstruktur dengan baik. Bahkan, pembelajarannya terkesan sporadis tanpa konsep yang matang. Kesadaran ideologis konseptual jangka panjang tentang proyek nasionalisme belum tampak di pondok-pondok pesantren saat ini. Polarisasi dalam kontestasi Pilpres dan Pileg pada 2019 di laman-laman website dan dinding-dinding media sosial seolah merupakan pantulan nyata masyarakat Indonesia di akar rumput. Para santri akhirnya belum mampu mengambil peranan secara optimal dalam penguatan nasionalisme di dunia nyata.

\footnotetext{
${ }^{44}$ Amin Farih, 'Nahdlatul Ulama (NU) Dan Kontribusinya Dalam Memperjuangkan Kemerdekaan Dan Mempertahankan Negara Kesatuan Republik Indonesia (NKRI)', Walisongo: Jurnal Penelitian Sosial Keagamaan, 2.Issue 2 (2016), 251-84.

${ }^{45}$ Mukodi dan Afid Burhanuddin.

${ }^{46}$ Wawancara dengan ustadzah Kholisah pada tanggal 11 April 2020.

${ }^{47}$ Mukodi, 'Pesantren Dan Pendidikan Politik Di Indonesia: Sebuah Reformulasi Kepemimpinan Islam Futuristik'.
} 
Dalam konteks tersebut, rancangan pendidikan nasionalisme dalam kurikulum di Pondok Pesantren Tremas yang tengah dipraktikkan sesungguhnya selaras dengan teori pengembangan kurikulum Ralph W. Tyler yang bertumpu pada empat prinsip, yakni: berhubungan dengan tujuan belajar yang ingin dicapai, berhubungan dengan pengalaman belajar untuk mencapai tujuan, berhubungan dengan pengorganisasian pengalaman belajar, dan berhubungan dengan pengembangan evaluasi. ${ }^{48}$ Di ranah tujuan belajar misalnya, para santri Pondok Tremas bebas memilih tujuan belajar. Para santri putri yang menginginkan hafalan alQuran mereka dapat tahasus ke dalem Bu Nyai Fuad (Nyai Inayah), ustadzah Masnu'atul Baroroh, dan ustadzah Siti Hajarah. Demikian pula dengan santri putra yang menghafalkan alQuran mekanismenya pun sama. Di ranah pengalaman belajar misalnya, forum khițābiyah merupakan ajang yang baik untuk menempa keilmuan santri di depan umum. Di ranah pengorganisasian pengalaman belajar misalnya, santri ditempa beragam kegiatan ekstra kurikuler di pondok. Di ranah pengembangan evaluasi, para santri dievaluasi dengan kegiatan imtihan (ujian) per triwulan sekali. ${ }^{49}$

Di Pondok Tremas konsep penanaman nilai-nilai nasionalisme yang berorientasi pada empat pilar kebangsaan ${ }^{50}$ telah diajarkan, hanya saja praktik baik tersebut, kurang disadari oleh para pengurus pondok. Adapun praktik penguatan nasionalisme dalam kurikulum di Pondok Tremas adalah sebagai berikut:

Tabel 2; Konsep Nasionalisme Kurikulum Pondok Pesantren

\begin{tabular}{|c|c|c|}
\hline Metode & Implementasi & Tujuan \\
\hline olah pikir & kajian kitab kuning & \multirow{4}{*}{$\begin{array}{l}\text { hidden curriculum } \\
\text { meneguhkan empat pilar } \\
\text { kebangsaan (Pancasila, } \\
\text { Bhineka Tunggal Ika, } \\
\text { NKRI, dan UUD 1945) } \\
\text { dalam jiwa santri dan } \\
\text { masyarakat luas }\end{array}$} \\
\hline olah hati & wirid dan istighasah & \\
\hline olah rasa & $\begin{array}{l}\text { implementasi panca jiwa santri } \\
\text { (kesederhanaan, kemandirian, } \\
\text { persaudaraan, kebebasan, kesahajaan) }\end{array}$ & \\
\hline olah karsa & $\begin{array}{l}\text { kegiatan di grass root (akar rumput), } \\
\text { langsung berinteraksi } \\
\text { masyarakat luas }\end{array}$ & \\
\hline
\end{tabular}

Catatan penting dari tabel 2 tersebut di atas, bahwa konsep nasionalis dalam kurikulum di Pondok Tremas dibangun melalui empat ranah secara sinergis-integral dan kontinu. Pertama, olah pikir. Olah pikir santri dilakukan melalui pembelajaran kitab kuning. Sebagai salah satu dirasah, kitab kuning diajarkan oleh kiai untuk mengisi, sekaligus menyemaikan jiwa intelektual santri. Melalui kitab kuning, para santri diajarkan bagaimana caranya ber-aqidah ilahiyah (ber-Tuhan), ber-muamalah (berdagang), ber-fiqih (beribadah), ber-siyasyiah (berpolitik), ber-tasawuf (bermunajat pada-Nya) dan lain sepadannya. Proses pengajarannya dilaksanakan sesuai dengan tingkat, usia, kemampuan dan kategori pondok pesantren masingmasing. Tidak ada aturan yang baku di setiap pondok pesantren, kurikulum pembelajaran disesuaikan dengan keilmuan sang kiai.

Kedua, olah hati. Para santri biasanya melaksanakan olah hati melalui wirid dan istigasah. ${ }^{51}$ Pada umumnya, kebanyakan pondok pesantren memiliki wirid-wirid khusus yang

\footnotetext{
${ }^{48}$ Sholeh Hidayat, Pengembangan Kurikulum Baru (Bandung: PT Remaja Rosdakarya, 2013).

${ }^{49}$ Wawancara mendalam dengan para santri dan ustadz/ustadzah Pondok Tremas pada medio Februari-April 2020.

${ }^{50}$ Pemahaman tentang Pancasila, Bhineka Tunggal Ika, Negara Kesatuan Republik Indonesia, Undang Undang Dasar 1945.

${ }^{51}$ Istilah istigasah merupakan serangkaian doa-doa yang dipanjatkan kepada Allah swt. untuk memohon pertolongan. Lihat, Ainani Zakiyatul Fuadah, 'Peran Istighasah Dalam Mengurangi Kecemasan Siswa
} 
wajib dibaca oleh para santri di pondok pesantren. Sebut saja bacaan wirid Surat Yasin dan Surat al-Waqiah sesudah Shalat Magrib dan Shalat Subuh. Hizib Nashr, Hizib Bahr, dan lain sepadannya. Bacaan istigasah pun demikian adanya, ia biasanya dibaca dan diamalkan secara terjadwal dan terprogram. Praktik bacaan wirid dan istigasah dilantunkan secara bersama-sama dan khidmat dipandu oleh sang kiai atau pengurus pondok.

Ketiga, olah rasa. Para santri mempraktikkan olah rasa melalui implementasi panca jiwa santri (kesederhanaan, kemandirian, persaudaraan, kebebasan, kesahajaan). Umumnya, setiap santri yang belajar di pondok pesantren salafiyah (tradisional), mereka mengalami dan melaksanakan panca jiwa santri sesuai dengan kemampuannya masing-masing. Hanya saja, jika dibandingkan dengan tempo dulu, kehidupan santri di masa kini jauh lebih mudah dan lebih nyaman. Baik infrastruktur bangunan fisik, akses jalan, sosial ekonomi, budaya, maupun ekonomi.

Keempat, olah karsa. Biasanya para santri mempraktikkan olah karsa (amaliyah) di grass root (akar rumput) dengan cara membaur dan bergumul tanpa sekat. Hal ini tergambar secara jelas, tatkala para santri mengikuti kegiatan sosial kemasyarakatan, seperti tahlihan, takziah, ziarah kubur, dan lain sebagainya.

Jadi, keempat ranah tersebut di atas, pada prinsipnya menguatkan simpul-simpul nasionalisme dalam relung sanubari jiwa santri selama yang bersangkutan mondok di Pondok Tremas. Dikemudian hari, tatkala para santri kembali ke kampung halaman, jiwa nasionalisme mereka telah terisi dan teruji, sehingga siap dan rela ikut serta menjaga keutuhan negara dan bangsa Indonesia dari pelbagai gangguan. Tujuan penanaman empat pilar kebangsaan pada kolom ke tiga tabel 2 tersebut di atas, di Pondok Tremas adalah sisi terlemah yang hanya dipahami oleh pengasuh pondok dan sebagian kecil dari ustadz dan ustadzah senior. ${ }^{52}$ Hal ini tentunya harus diperbaiki dan dilakukan pemahaman kolektif agar hidden curriculum-nya tersampaikan.

\section{E. Model Penguatan Nasionalisme Di Pondok Pesantren Tremas: Menangkal Penyebaran Radikalisme dan Islam Transnasional}

Model penguatan nasionalisme di Pondok Tremas telah dilaksanakan melalui dua ranah, yakni dalam bentuk pemikiran dan dalam bentuk tindakan. Penguatan nasionalisme dalam bentuk pemikiran ditanamkan, melalui pikiran-pikiran sang kiai, ustadz dan ustadzah terkait dengan nilai-nilai nasionalisme yang disebarluaskan kepada para santri saat melaksanakan pendidikan, dan pengajaran di dalam pondok. Penguatan nilai-nilai nasionalisme dalam bentuk tindakan dilaksanakan oleh sang kiai, ustadz dan ustadzah secara langsung sehingga para santri dapat melihat dan meniru praktik baik tersebut.

Pada saat perayaan hari kemerdekaan misalnya, sang kiai memasang Bendera Merah Putih di halaman pondok, memerintahkan santri untuk mengikuti upacara bendera, dan menggelar aneka perlombaan yang menumbuhkan jiwa nasionalisme dalam jiwa santri, dan lain sebagainya. Dengan demikian, penguatan nasionalisme dalam bentuk pemikiran dan tindakan tersebut di atas, akan menginternalisasi dalam jiwa raga santri, dikemudian hari akan menjadi pembiasaan-pembiasaan yang baik bagi mereka. Praktik-praktik yang terkait dengan nilai-nilai nasionalisme, baik berupa pemikiran maupun tindakan santri akan dibawa dan dipraktikkan para santri di kampung halaman mereka.

Di area inilah nilai-nilai nasionalisme akan senantiasa diproduksi dan dibudayakan oleh sang santri atau alumni tersebut, bahkan jika yang bersangkutan menjadi kiai kampung

Menghadapi Ujian Nasional Di UPTD SMAN I Mojo Kediri: Kajian Fenomenologis Psikosufistik Pendidikan Islam', Didaktika Religia, 2.Issue 2 (2014), 120. 2020 .

${ }^{52}$ Hasil observasi peneliti dan wawancara dengan santri senior Pondok Tremas pada medio Maret-April 
pengaruhnya akan semakin kuat dan luas. Secara otomatis praktik-praktik baik penguatan nasionalisme akan semakin luas dan membudaya. Semakin kuat praktik dan penguatan nasionalisme di pondok pesantren, maka pondok pesantren tersebut, semakin dominan menangkal penyebaran paham radikalisme dan Islam transnasional sulit masuk, apalagi berkembang di pondok tersebut. Sebaliknya jika pondok pesantren lemah dalam memberikan pengauatan nasionalisme, maka pondok pesantren akan mudah dimasuki dan terpapar paham radikalisme dan Islam trans nasional.

Berikut ini akan dijelaskan skema model penguatan nasionalisme di Pondok Tremas dalam menangkal penyebaran radikalisme dan Islam transnasional.

Skema 1: Konsep Penguatan Nasionalisme Di Pondok Tremas

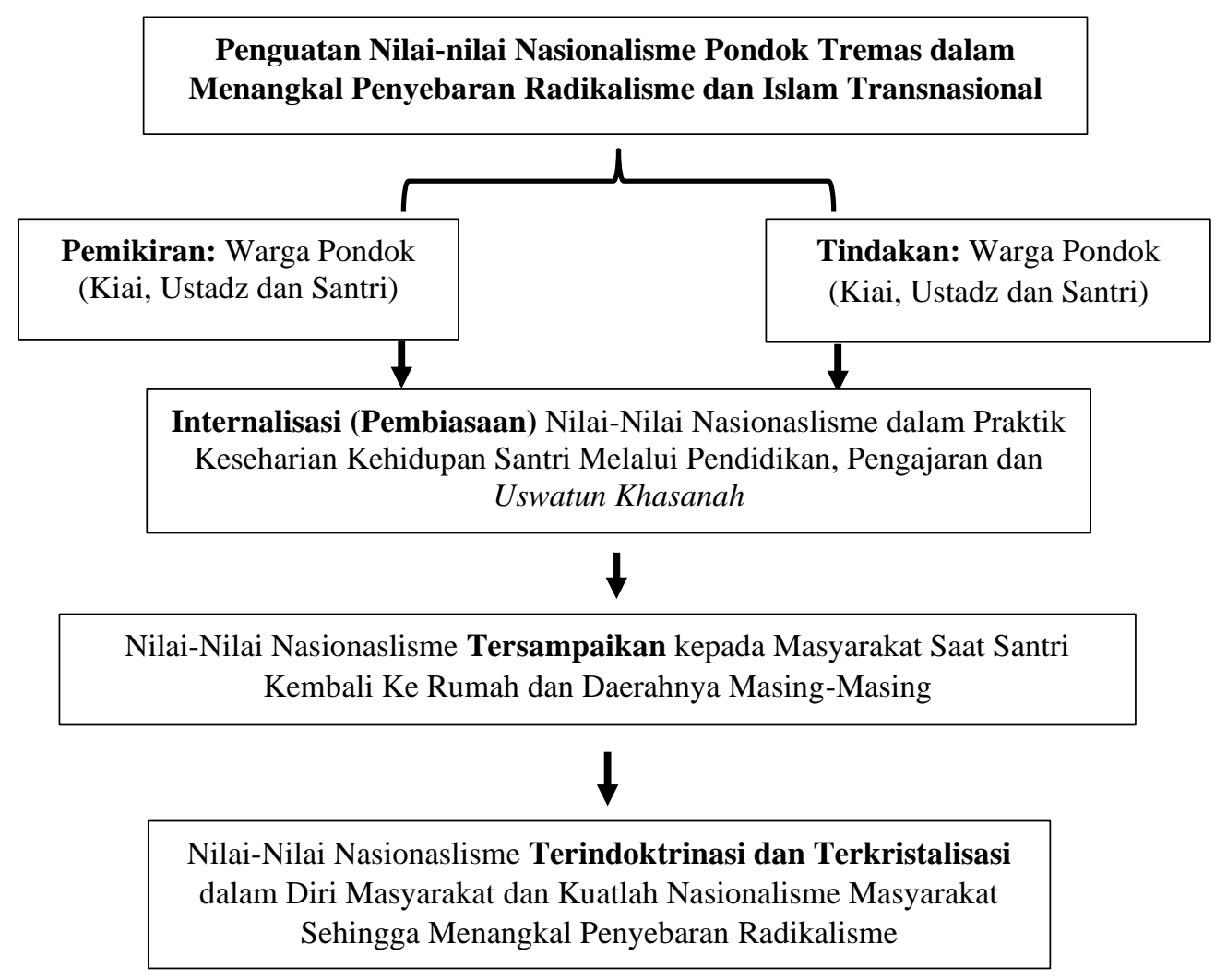

Konsep tersebut di atas, pada prinsipnya merupakan penguatan nilai-nilai nasionalisme di Pondok Tremas dalam menangkal penyebaran radikalisme dan Islam transnasional. Konsep penguatan nasionalisme tersebut di atas, tentunya dapat secara mudah dan efektif dilaksanakan di pondok pesantren lainnya dengan catatan ada komitmen dari sang kiai yang akan melahirkan budaya organisasi yang baik di pondok. ${ }^{53}$

\section{F. Penutup}

Kurikulum Pondok Tremas hingga saat masih mempertahankan ciri khas ke-salafiyahan (tradisional) melalui kitab-kitab mu'tabarah sebagai materi ajar yang ditransformasikan kepada para santri. Konsep nasionalisme dalam pembelajaran dilaksanakan melalui pengajaran kitab kuning, baik dengan metode sorogan, bandongan, maupun tahasus. Selain itu, juga disampaikan melalui ceramah-ceramah keagamaan yang dilaksanakan oleh pengasuh dan ustadz / dzah senior Pondok Tremas secara insidental. Rancangan konsep nasionalisme Pondok Tremas menggunakan pola pengembangan kurikulum Ralph W. Tyler yang fokus pada tujuan

${ }^{53}$ Lihat, John P. Kotter dan James L. Heskett, Corporate Culture and Performance (Jakarta: PT. Prenhallindo, 1997). 
belajar, pengalaman belajar, organisasi pengalaman, dan pengembangan evaluasi santri. Keempat ranah tersebut, diarahkan pada penguatan nasionalisme dalam bentuk real curriculum dan hidden curriculum yang dinahkodai oleh kedua pengasuh (KH. Fuad Habib Dimyathi dan KH. Lukman Hakim Harist Dimyathi). Model penguatan nasionalisme Pondok Tremas dilaksanakan dalam pemikiran dan penguatan yang dilakukan oleh kedua pengasuh secara simultan dan kontinu.

\section{DAFTAR PUSTAKA}

Abdul Rasyid Saliman dan Rio Armanda Agustian, 'Menguatkan Nasionalisme Baru Generasi Muda yang Berkarakter (Dalam Upaya Mengembangkan Model Pencegahan Radikalisme dan Terorisme Di Kampus)', in Seminar Nasional Hukum Universitas Negeri Semarang (Semarang: Universitas Negeri Semarang, 2017), pp. 129-34

Ainani Zakiyatul Fuadah, 'Peran Istighasah dalam Mengurangi Kecemasan Siswa Menghadapi Ujian Nasional Di UPTD SMAN I Mojo Kediri: Kajian Fenomenologis Psikosufistik Pendidikan Islam', Didaktika Religia, 2.Issue 2 (2014), 120

Al-Syaibani, Oemar Muhammad Al-Toumy, Filsafat Pendidikan Islam, Hasan Lang (Jakarta: Bulan Bintang, 1979)

Al-Syaibany, O.M.A., Falsafah Pendidikan Islam (Jakarta: Bulan Bintang, 1979)

Amin Farih, 'Nahdlatul Ulama (NU) dan Kontribusinya dalam Memperjuangkan Kemerdekaan dan Mempertahankan Negara Kesatuan Republik Indonesia (NKRI)', Walisongo: Jurnal Penelitian Sosial Keagamaan, 2.Issue 2 (2016), 251-84

Bruinessen, M.V., Kitab Kuning Pesantren Dan Tarekat (Jakarta: Mizan, 1995)

Dhofier, Z., Tradisi Pesantren Studi Pandangan Hidup Kyai dan Visinya Mengenai Masa Depan Indonesia (Jakarta: LP3ES, 2011)

H. Langgulung, Manusia dan Pendidikan: Suatu Analisa Psikologi Pendidikan (Jakarta: Bumi Aksara, 1986)

Harun Nasution, Kurikulum dan Pengajaran (Jakarta: Bumi Aksara, 1995)

IrwanNahar, Novi, 'Penerapan Teori Belajarbehavioristik Dalam Prosespembelajaran', Nusantara (Jurnal Ilmu Pengetahuan Sosial), 1 (2016), 65-66

John P. Kotter dan James L. Heskett, Corporate Culture and Performance (Jakarta: PT. Prenhallindo, 1997)

Lombard, D, Nusa Jawa: Silang Budaya (Jakarta: Gremedia Pustaka Utama, 2008)

Mujib, A. \& Mudzakkir, J., Ilmu Pendidikan Islam (Jakarta: Kencana Prenada Media Group, 2008)

Mukodi, Menjaga Umat: Pilar-Pilar Budaya Pondok Tremas Pacitan di Era Global, 1st edn (Yogyakarta: Lentera Kresindo, 2015)

__, 'Pesantren Dan Pendidikan Politik di Indonesia: Sebuah Reformulasi Kepemimpinan Islam Futuristik', Al-Tahrir Jurnal Pemikiran Islam, 16 (2016), 462-63

—, 'Pesantren Dan Upaya Deradikalisasi Agama', Jurnal Walisongo, 23.Issue 1 (2015)

Mukodi dan Afid Burhanuddin, 'Dialektika Keilmuan Pondok Pesantren Tremas Dalam Perspektif Gender', Jurnal Penelitian Pendidikan, 7.Issue 1 (2015)

Nasihun Amin, 'Menyemai Nasionalisme dari Spirit Agama: Upaya Meredam Radikalisme Beragama', Jurnal Teologia, 23.Issue 1 (2012)

Noeng Muhadjir, Metodologi Penelitian Paradigma Positivisme Objektif Phenomenologi Interpretif Logika Bahasa Platonis, Chomskyist, Hegelian \& Hermeneutik Paradigma Studi Islam Matematik Recursion, Seft-Theory \& Stuructural Equation Modeling Dan Mixed, Edisi VI P (Yogyakarta: Rake Sarasin, 2011)

Nurcholis Madjid, Bilik-Bilik Pesantren Sebuah Potret Perjalanan (Jakarta: Paramadina, 2010) Nurrohman, Pesantren Sebagai Penangkal Radikalisme dan Terorisme: Studi Terhadap 
Pandangan Pimpinan Pesantren di Bandung Tentang Jihad, Kekerasan dan Kekuasaan, Serta Cara Menangkal Munculnya Radikalisme Dan Terorisme (Jakarta, 2010)

Samsul Ma'arif, 'Ideologi Pesantren Salaf: Deradikalisasi Agama Dan Budaya Damai', Ibda' Jurnal Kebudayaan Islam, Vol. 12.No. 2 (2014), 201

Shofiyullah Mz., 'Al-Kutub Al-Mu'tabarah: Kajian atas Sumber Rujukan dalam Beristinbat Menurut NU, Muhammadiyah, Dan Persis', Jurnal Asy-Syir'ah, 42.Issue 1 (2008), 38-54 Sholeh Hidayat, Pengembangan Kurikulum Baru (Bandung: PT Remaja Rosdakarya, 2013) Sutarjo Adisusilo, 'Nasionalisme-Demokrasi-Civil Society' (Jakarta: www.google, diakses 28/06/2019, pukul 16.03., 2019)

Tn, 'Kamus Besar Bahasa Indonesia (KBBI) Online' (https://kbbi.web.id/)

Yaqut Cholil Qoumas, 'Menjaga Rumah Pancasila dari Ancaman Ideologi Islam Transnasional', Tirto.Id (Jakarta, June 2019), p. 1 